Hubertus R. Drobner

Theologische Fakultät Paderborn

Paderborn, Germany

drobner@zitmail.uni-paderborn.de

\title{
DAILY LIFE IN THE PREACHING OF GREGORY OF NYSSA AND AUGUSTINE OF HIPPO
}

Time and again scholars have wondered whether the numerous remarkable similarities between Gregory of Nyssa's and Augustine of Hippo's thoughts justify supposing a direct dependency. As early as in 1781 Christian Gottlieb Glauber published a parallel translation of Gregory's Oratio catechetica and Augustine's De catechizandis rudibus. ${ }^{1}$ The most recent contribution to the debate was, in 2010, a small monograph by Jan Eike Welchering on Eucharist and Divinisation. An Introduction to Theosis in Augustine and Gregory of Nyssa. ${ }^{2}$ The major focal points of interest were especially provided by:

their theology proper, in particular their discourses on the trinity and the infinity of God, ${ }^{3}$

their mysticism, above all the idea of the ascent of the human soul towards God and the subsequent infinite progress in Him, ${ }^{4}$

(1) Ch. G. Glauber, Gregorius von Nyssa und Augustinus über den ersten christlichen Religionsunterricht. Aus dem Griechischen und Lateinischen übersetzt, mit Anmerkungen, Leipzig, 1781.

(2) J. E. Welchering, Eucharistie und Vergöttlichung. Einführung in die Theosis bei Augustinus und Gregor von Nyssa (Pons Theologiae, 2), München, 2010, 20112.

(3) Cf. G. B. Ladner, "St. Gregory of Nyssa and St. Augustine on the Symbolism of the Cross", in Late Classical and Mediaeval Studies in Honor of Albert Mathias Friend Jr., ed. by K. Weitzmann, Princeton, N.J., 1955, pp. 88-95; P. Courcelle, Les Confessions de Saint Augustin dans la tradition littéraire, Paris, 1963, p. 252, n. 1; O. Du Roy, L'intelligence de la foi en la trinité selon saint Augustin. Génèse de sa théologie trinitaire jusqu'en 391, Paris, 1966, p. 265, n. 3; L. Sweeney, "Augustine and Gregory of Nyssa: Is the Triune God Infinite in Being?" in Augustine: Presbyter Factus Sum, ed. by J. T. Lienhard, E. C. Muller, R. J. Teske (Collectanea Augustiniana), New York, 1993, pp. 497-516.

(4) Cf. A. A. Weiswurm, The Nature of Human Knowledge According to Saint Gregory of Nyssa (The Catholic University of America Philosophical Studies, 
their common platonic philosophy, for instance, regarding man as the image of God, ${ }^{5}$

and their catecheses.

Despite manifold parallels and similarities direct dependency can neither be proved nor disproved. Given the fact that in the fourth and fifth centuries Gregory's works had not been translated into Latin yet (the first known translation of a complete work of Gregory's is the Latin version of De hominis opificio by Dionysius Exiguus, c. $470-c .550){ }^{6}$ and because of Augustine's rather wanting knowledge of Greek ${ }^{7}$ most

136), Washington. D.C., 1952; W. VöLKeR, Gregor von Nyssa als Mystiker, Wiesbaden, 1955; C. W. Macleod, "ANA $\Upsilon \Upsilon \Sigma \mathrm{I} \Sigma$ : A Study in Ancient Mysticism," Journal of Theological Studies, N. S. 21 (1970), pp. 43-55 (53); M.-B. von StRitzKY, "Beobachtungen zur Verbindung zwischen Gregor von Nyssa und Augustin," VC, 28 (1974), S. 176-185.

(5) Cf. J. F. Callahan, Augustine and the Greek Philosophers. The Saint Augustine Lecture 1964, Villanova, P.A., 1967; E. MüHLEnberG, "Synergism in Gregory of Nyssa," Zeitschrift für die neutestamentliche Wissenschaft, 68 (1977), pp. 93-122 (104-112).

(6) Cf. H. B. Wicher, "Gregorius Nyssenus," in Catalogus Translationum et Commentariorum: Mediaeval and Renaissance Latin Translations and Commentaries. Annotated Lists and Guides, vol. 5, ed. by P. O. Kristeller, F. E. Cranz, Washington, D.C., 1984, p. 22.

(7) Cf. O. Rottmanner, "Zur Sprachkenntnis des hl. Augustinus," Theologische Quartalschrift, 77 (1895), S. 269-276; S. SALAVILle, "La connaissance du grec chez saint Augustin," Échos d'Orient, 21 (1922), pp. 387-393; P. Guilloux, "Saint Augustin savait-il le grec?" Revue d'Histoire Écclésiastique, 21 (1925), pp. 79-83; B. Altaner, "Augustinus und die griechische Sprache," in Pisciculi (Festschrift Franz Josef Dölger), hrsg. Th. Klauser, A. RücKer (Antike und Christentum, Ergänzungsband 1), Münster, 1939, S. 19-40 [repr. in Kleine patristische Schriften, hrsg. G. Glockmann, Berlin, 1967, S. 129-153]; L. Finale Montalbano, "Sulla conoscenza del greco di S. Agostino," Humanitas, 6 (1951), pp. 1095-1097; M. Mellet, Th. Camelot, "Note complémentaire 24: Augustin et le grec," in Bibliothèque Augustinienne, 15 (1955; 1991²), pp. 579f.; A. Solignac, "Note complémentaire 6: A quel point Augustin savait-il le grec?" in Bibliothèque Augustinienne, 13 (1962; 1992²), p. 662; H. I. Marrou, Augustinus und das Ende der antiken Bildung, Paderborn, 1981, pp. 25-41; G. J. M. BARTELINK, "Die Beeinflussung Augustins durch die griechischen Patres," in Augustiniana Traiectina. Communications présentées au Colloque International d'Utrecht, 13-14 novembre 1986, ed. by J. DEN Boeft, Paris, 1987, pp. 9-24 (20-22); A. LÉvY, "Porphyrius Christianus. L'intégration différenciée du platonisme à la fin du IV siècle (S. Grégoire de Nysse/S. Augustin d'Hippone)," in Revue des Sciences Philosophiques et Théologiques, 88 (2004), pp. 673-704. 
scholars tend to negate any direct connection. ${ }^{8}$ On the other hand, Almut Mutzenbecher maintained that, in his Commentary on the Sermon on the Mount, Augustine could have derived a number of key concepts only directly from Gregory of Nyssa's Homilies on the Beatitudes, not mediated by St. Ambrose. ${ }^{9}$ At any rate, as Gerhart B. Ladner put it, in 1955, "St. Gregory of Nyssa and St. Augustine ...represent the maturity of patristic speculative thought in Greek and Latin Christendom,"10 which alone calls for and justifies further comparative studies.

So far research has focussed on Gregory's and Augustine's philosophy and theology. Their homiletic use of the events of daily life both as a methodology of preaching and as archaeological and historical sources have been given little attention so far; also owed to the fact

(8) Cf. K. Adam, Die Eucharistielehre des hl. Augustin (Forschungen zur christlichen Literatur- und Dogmengeschichte, 8/1), Paderborn, 1908, S. 43; B. Altaner, "Augustinus, Gregor von Nazianz, Gregor von Nyssa", Revue Bénédictine, 61 (1951), S. 54-62 (62) [rep. in Kleine patristische Schriften, hrsg. G. GlockmanN, Berlin, 1967, S. 277-285 (285)]; von StritzKy [note 4], S. 176f., 185; A. Meredith, "Gregory of Nyssa, De beatitudinibus, Oratio I: 'Blessed are the Poor in Spirit, for Theirs is the Kingdom of Heaven' (Mt 5:3)," in Gregory of Nyssa, Homilies on the Beatitudes. An English Version with Commentary and Supporting Studies. Proceedings of the Eighth International Colloquium on Gregory of Nyssa (Paderborn, 14-18 September 1998), ed. by H. R. Drobner, A. Viciano (VC Supp., 52), Leiden, 2000, pp. 93-109 (94): “The possibility of any influence of Gregory on Augustine can, I think, be ruled out." Nevertheless, Meredith quotes further parallels of Gregory and Augustine on pp. 97 and 106.

(9) Cf. Sancti Aurelii Augustini De Sermone Domini in Monte libros duos post Maurinorum recensionem, ed. by A. MutzenbeCher (CCL, 35), Turnhout, 1967, p. XV: "...entsteht der Eindruck, dass hier direkte Abhängigkeit vorliegt", with note 6 discussing Augustine's knowledge of Greek and the Latin translations of Gregory's works; Bartelink, "Die Beeinflussung Augustins," S. 21f. Further discussion of those parallels by Meredith, "Gregory of Nyssa, De beatitudinibus," A. SPIRA, "Gregor von Nyssa, De beatitudinibus, Oratio II: 'Selig sind die Sanftmütigen, denn sie werden das Erdreich besitzen' (Mt 5:4)," in Gregory of Nyssa, Homilies on the Beatitudes. An English Version with Commentary and Supporting Studies. Proceedings of the Eighth International Colloquium on Gregory of Nyssa (Paderborn, 14-18 September 1998), ed. by H. R. Drobner, A. Viciano (VC Supp., 52), Leiden, 2000, pp. 113, 121; R. L. Wilken, “Gregory of Nyssa, De beatitudinibus, Oratio VIII: 'Blessed are Those Who Are Persecuted for Their Righteousness' Sake, for Theirs is the Kingdom of Heaven' (Mt 5:10)", in Ibid., pp. 244, 253.

(10) Cf. Ladner, "St. Gregory of Nyssa and St. Augustine," p. 88. 
that this line of inquiry, in general, is a comparatively recent one. ${ }^{11}$ Of course, direct historical references have always been noted and made use of, while the indirect kind of references as used in metaphors, comparisons, images, parables and similes rarely received attention. Nevertheless, Gregory and Augustine use them so extraordinarily frequently in their respective works like no other author in Christian antiquity (this general claim be permitted as the result of many years of studies without providing statistical proof). And even if no direct link can be established between them, it shows that they had a certain way of thinking and expressing themselves in common that marks them as cognate souls and which, therefore, deserves joint investigation. Here is a representative example from each one of them:

In sermon 340/A, 10 (= Guelferbytanus 32) Augustine says to his audience:

Here is another comparison for you to consider. Do not gather grapes from thorns (cf. Mt 7:16); after all it is impossible for grapes to be produced from thorns. But have you not noticed vine shoot getting into a hedge as it grows, and entwining itself in the thorns, and putting forth buds among the thorns, and producing bunches of grapes?

You are hungry, and you are walking past, and you see a bunch hanging among the thorns; you ....are hungry and want to pick it. Pick it then; stretch out your hand carefully and attentively; beware of the thorns, pick the fruit.

In the same way, too, when a bad or worthless man speaks the teaching of Christ to you, listen to it, accept it, do not ignore it. If he is a bad man, the thorns are his; if he says good things, it is the bunch hanging among the thorns, it is not growing from the thorns. ${ }^{12}$

(11) Cf. e.g. M. Dulaey, "La parabole de la brebis perdue dans l'Église ancienne: De l'exégèse à l'iconographie," Revue des Études Augustiniennes, 39 (1993), pp. 3-22; H. R. Drobner, Archaeologia Patristica. Die Schriften der Kirchenväter als Quellen der Archäologie und Kulturgeschichte: Gregor von Nyssa, Homiliae in Ecclesiasten (Sussidi allo Studio delle Antichità Cristiane, 10), Vatican City, 1996; IDEM, "Die Palästina-Itinerarien der Alten Kirche als literarische, historische und archäologische Quellen" Augustinianum, 38 (1998), S. 293-354; IDEM, "'You Cannot Pick Grapes from Thorns': Saint Augustine's Imagery - Archaeological Evidence and Spiritual Meaning," Melita Theologica, 51 (2000), pp. 25-37.

(12) Translation taken from: The Works of Saint Augustine. A Translation for the 21st Century III/9: Sermons on the Saints (306-340A), transl. and notes by E. Hill, ed. by J. E. Rotelle, Hyde Park, N.Y., 1994, 303 f. 
Gregory of Nyssa says in his Homily 8 on Ecclesiastes:

It is as if someone has set out on a table all the preparations for a banquet where to put certain implements alongside suitable to help with eating, the sort of things manufactured by specialized craftsmen, small knives with which the diners cut up some of the food offered them, or silver prongs made with a hollow part attached to one end convenient for holding soup; then one of the guests at the dinner changes the function of what lies before him and uses each for the wrong purpose, and cuts with his knife either himself or one of the people sitting next to him, and with his prong pierces his neighbour's eye or his own; you might say that this person misused his host's cutlery, not because the one who provided it prepared beforehand the cause of what happened, but because the wrong use of the things laid out led to this disaster the one used stupidly what lay before him. ..."In just the same way," he says, "I too know that each thing comes from God for all good, as long as use is made of it at the right moment for a proper purpose, but the perversion of right judgment about reality turns good things into the beginning of evils. ...Therefore," he says, "all things which he made are good at his right moment" (Eccl 3:11). ${ }^{13}$

In both cases, the ultimate catechetical aim of the preacher is a theological and spiritual one, also accompanied by practical advice. On this immediate level these texts are usually interpreted. Nevertheless, there are at least two more levels of analysis which may not be neglected lest even the spiritual aim be misunderstood or not sufficiently comprehended, which are the material and the rhetorical analyses.

For instance, in Homily 3 on Ecclesiastes, Gregory of Nyssa says:

This is like the case of a person who through excessive greed accumulates in himself a mixture of indigestible fluids, and then, when his body develops a fever, is treated with lancing and cauterization and has the disease as a sort of tutor in discipline for the rest of his life as he sees the scar of cauterization on his body. ${ }^{14}$

(13) Translation taken from: Gregory, Bishop of Nyssa, Homilies on Ecclesiastes. Translation by St. G. Hall, R. Moriarty, in: Gregory of Nyssa, Homilies on Ecclesiastes. An English Version with Supporting Studies. Proceedings of the Seventh International Colloquium on Gregory of Nyssa (St Andrews, 5-10 September 1990), ed. by St. G. HaLl, Berlin-New York, 1993, pp. 31-144 (142).

(14) Transl. by Hall, Moriarty, Gregory of Nyssa, Homilies on Ecclesiastes, p. 61. Greek text in: Gregorii Nysseni In Ecclesiasten Homiliae, ed. by P. AlexanDER, in: Gregorii Nysseni Opera V, Leiden, 1962, pp. 195-442 (317.5-9). 


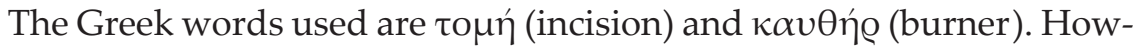
ever, if one has no idea which kind of surgery this cutting refers to, and what kind of instrument a $\kappa \alpha v \theta \eta$ @ is, the whole effort of the preacher is lost. This holds true both for the immediate audience in antiquity and the modern reader. Consequently, one must assume that Gregory presupposed that his audience knew what he was referring to. Thus, the more different similes are used in the same text, the more information they provide about the audience present and their daily life.

For the modern reader who is 1600 years removed from the original scene, it is sometimes not so easy to understand what is really meant. "Cutting" and "burning" in order the cure the accumulation of detrimental fluids resulting in a permanent scar, all this makes little sense, if one has never heard of the ancient theory of the right balance of four fluids in the human body which determine its health, ${ }^{15}$ if, furthermore, one does not know anything about surgery and blood-letting as a popular medical means of treatment, ${ }^{16}$ and, finally, one even needs to know from experience what a scar is, what it looks like and how one acquires it. Nevertheless, even being equipped with all this information, without having an idea what the instruments, which were actually used, looked like, the understanding of the exact procedure will still remain somewhat clouded. Only combining the text at hand with other written testimonies, and in conjunction with the material findings of scalpels and medical cauterization irons, one finally draws as close to the understanding of the ancient audience as possible.

The Roman scalpel is made from a combination of a cast-bronze handle with an inserted and exchangeable iron or steel blade. ... Completely preserved scalpels from tombs of physicians in Bingen

(15) Cf. M. E. Keenan, "St. Gregory of Nyssa and the Medical Profession," Bulletin of the History of Medicine, 15 (1944), pp. 150-161 (156); E. SCHönER, Das Viererschema in der antiken Humoralpathologie, pref. by R. HERrLINGER (Sudhoffs Archiv für Geschichte der Medizin und der Naturwissenschaften, Beiheft 4), Wiesbaden, 1964; R. JAcKson, Doctors and Diseases in the Roman Empire, London, 1988, pp. 32-40.

(16) Cf. B. Scнüтt, Geschichte der Blutstillung vom Altertum bis zur Zeit des Ambroise Paré, Thesis, Berlin, 1932, S. 8-32; H. J. Frings, Medizin und Arzt bei den griechischen Kirchenvätern bis Chrysostomus, Thesis, Bonn, 1959, S. 73-77; G. Penso, La médicine romaine. L'art d'Esculape dans la Rome antique, Paris, 1984, pp. 421-424; G. LoREnZ, Antike Krankenbehandlung in historisch-vergleichender Sicht. Studien zum konkret-anschaulichen Denken, Heidelberg, 1990, S. 22-26, 78-134, 173-209. 
and Pompei show that the blades either had the shape of a crescent or were straight and narrow, occasionally also similar to a sickle.... The end of the handle was form like a lancet or spatula and served for spreading the edges of the wound during surgery ${ }^{17}$ (see Plate 1).

The cauterization iron ...was usually made of iron; this is the reason why so few have been preserved. However, there were also some made of bronze, gold or silver. Different in form and size, it was put to various and often unique uses: in order to staunch blood, to remove tumors, to disinfect injuries and wounds, to lance fistulae, and open infected cavities. ...Its forms were extremely varied: a long, thin iron with an olive-shaped end; formed like a sickle, a scoop or a tube; similar to the Greek letter Chi or the Greek coin Obolos, formed like a nail, a needle, or a wedge. Sometimes cauterization irons were inserted into a tube of terracotta in order to protect the surrounding tissue from the heat ${ }^{18}$ (see Plate 2).

Also recent articles on Saint Augustine are interested in the medical imagery in his preaching. ${ }^{19}$ However, they fail to compare the texts with the material reality of the time. In De civitate Dei, XXII 8.3 Augustine describes the treatment of an abscess (fistula) by cutting it open with an iron (sectio/secare ferro) or administering some medicin (medicamentum). Jean-Marie André quotes this passage as an example of Augustine's knowledge of the "Greco-Roman medical culture" and compares it to the ideas of the various medical schools in antiquity. Nevertheless, without explaining what the iron used looked like and how it worked, and what the medicine consisted of, the modern lis-

(17) H. МаттнёUs, “Medizinische Instrumente der römischen Kaiserzeit in Zypern. Untersuchungen zu einem Neufund aus Kourion," in: Studies in

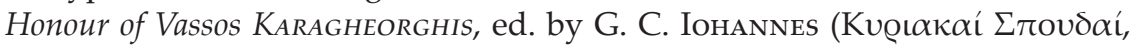
54-55), Leukousia, 1992, S. 314-316. Cf. J. St. Milne, Surgical Instruments in Greek and Roman Times, Oxford, 1907, pp. 24-50; M. TABANELli, Lo strumento chirurgico e la sua storia. Dalle epoche greca e romana al secolo decimosesto, Forli, 1958, pp. 57-63; R. JACKson, "A Set of Roman Medical Instruments from Italy," Britannia, 17 (1986), pp. 119-167; Drobner, Archaeologia Patristica, pp. 73-77.

(18) Tabanelli [note 17], p. 101. Cf. Milne [note 17], pp. 116-120; DrobNER, Archaeologia Patristica [note 11], pp. $77 \mathrm{f}$.

(19) Cf. S. Blackburn griffith, "Medical Imagery in the 'New' Sermons of Augustine," SP, 43 (2006), pp. 107-112; J.-M. AndRÉ, "Saint Augustin et la culture medicale greco-romaine: La cultura scientifico-naturalistica nei Padri della Chiesa (I-V sec.)," in: XXXV Incontro di studiosi dell'antichità cristiana, 4-6 maggio 2006 (Studia Ephemeridis 'Augustinianum', 101), Rome, 2007, pp. 597-604. 
tener only receives a general impression according to his own, modern experience, not the same, vivid and immediate one the ancient audience remembered and imagined, respectively.

Same is true for Susan Blackburn Griffith's article on "Medical Imagery in the 'New' Sermons of Augustine". Her interest in the "medical metaphors" (p. 107) is confined to their theological and spiritual intention, while leaving aside their real context. For instance, from the usage of the word poculum for the cup the physician offers his medicine in, in Sermon Dolbeau, 25.17 (=360/B), Blackburn Griffith concludes that it "could clearly allude to the cup of the Eucharist, since patristic Latin usage, while favouring calix, does occasionally opt for poculum" (p. 109). The literary analysis will certainly be right. However, what image does poculum evoke in the ancient listener? Was there a material difference between poculum and calix and their respective usages? May that not make all the difference whether the ancient audience really thought of the eucharist as the merely literary analysis suggests to the modern reader?

One may be inclined to think that in the case of well-known, everyday instruments and procedures such a thorough and detailed analysis is unnecessary. However, it can be very misleading to transfer modern concepts and usages to antiquity without close examination. The above-mentioned case of the silver spoons with a pronged handle provides a striking example. More than five-hundred silver spoons have been excavated from tombs in Europe and the Near-East, dating from the second to the seventh century A.D. ${ }^{20}$ However, the rest of the table-ware found in the tombs was usually of lesser material value

(20) Cf. V. Milojčıć, "Zu den spätkaiserzeitlichen und merowingischen Silberlöffeln. Mit einem Beitrag von H. Vetters," Bericht der Römisch-Germanischen Kommission. Deutsches Archäologisches Institut, 49 (1968), S. 111-152; H. W. Böнме, "Löffelbeigabe in spätrömischen Gräbern nördlich der Alpen," Jahrbuch des Römisch-Germanischen Zentralmuseums Mainz, 17 (1970), S. 172-200 (191-200); D. SHERLOCK, "Zu einer Fundliste antiker Silberlöffel. Nachträge und Ergänzungen," Bericht der Römisch-Germanischen Kommission. Deutsches Archäologisches Institut, 54 (1973), S. 203-211; M. Martin, Eßlöffel: Der spätrömische Silberschatz von Kaiseraugst (Basler Beiträge zur Ur- und Frühgeschichte, 9), Derendingen, 1984, S. 56-96; St. R. HAuser, Spätantike und frühbyzantinische Silberlöffel. Bemerkungen zur Produktion von Luxusgütern im 5. bis 7. Jahrhundert (Jahrbuch für Antike und Christentum. Ergänzungsbände, 19), Münster, 1992; C. Johns, J. Pickin, “Late Roman Silver Spoons from Spennymoor, County Durham," Britannia, 24 (1993), pp. 257-261; L. SCHwinden, “Ein spätrömischer Silberlöffel aus Trier mit Inschrift INVENITA VINCAS," Funde 
(iron, bronze, wood, or clay) ${ }^{21}$, and some of them were engraved with religious names and invocations like + C I M $\Omega \mathrm{N}$ (Istanbul: plate 3) or Deo gratias (Cologne-Müngersdorf: plate 4$).{ }^{22}$ Because only in the Western Empire literary evidence was known regarding the use of silver spoons at table,$^{23}$ and because in the Eastern Church the liturgical custom has been preserved to use a spoon for distributing the eucharist under both species, scholars surmised that those precious spoons were liturgical items, not meant for everyday use at home. ${ }^{24}$ Gregory's text proved this conclusion, which compared to modern experience appeared so plausible, as erroneous.

Consequently, a thorough and unprejudiced combined analysis of the ancient texts and monuments is always indicated, especially when things seem rather obvious in the light of modern experience. Nevertheless, this is a field of research that hitherto remains almost completely unplowed.

Finally, the rhetorical function of those texts requires at least a brief comment. There can be little doubt as to the basic influence of the parables of the Bible ${ }^{25}$ and the famous similes in the poems of Homer and Vergil. ${ }^{26}$ As the former is the fundamental text of Christendom,

und Ausgrabungen im Bezirk Trier. Aus der Arbeit des Rheinischen Landesmuseums Trier, 25 (1993), S. 26-35.

(21) Cf. Bӧнме, "Löffelbeigabe in spätrömischen Gräbern,” S. 172-200.

(22) Cf. Hauser, Spätantike und frühbyzantinische Silberlöffel, S. 115, Anm. 117, Pl. 3a, 17f.

(23) Cf. Possidius of Calama, Vita Augustini, 22.5: "Coclearibus tantum argenteis utens, ceterum vasa, quibus mensae inferebantur cibi, vel testea vel lignea vel marmorea fuerunt, non tamen necessitatis inopia, sed proposito voluntatis"; Hauser, Spätantike und frühbyzantinische Silberlöffel, S. 78-87; Drobner, Archaeologia Patristica, S. 180f., 186f.

(24) Cf. e.g. H. von Petrikovits, "Frühchristliche Silberlöffel," in Corolla Memoriae. Erich SwoвоdA dedicata (Römische Forschungen in Niederösterreich, 5), Graz-Köln, 1966, S. 173-182 (179). Against this thesis, see, e.g. J. Engemann, "Anmerkungen zu spätantiken Geräten des Alltagslebens mit christlichen Bildern, Symbolen und Inschriften," Jahrbuch für Antike und Christentum, 15 (1972), S. 171, Anm. 116.

(25) Cf. e.g. Ch. MüNch, Die Gleichnisse Jesu im Matthäusevangelium (WMANT, 104), Neukirchen, 2004.

(26) Cf. e.g. H. FräNKel, Die homerischen Gleichnisse, Göttingen, 1921; 1977²; R. A. Hornsby, Pattern of Action in the Aeneid. An Interpretation of Vergil's Epic Similes, Iowa City, 1970; G. CARlson, Die Verwandlung der homerischen Gleichnisse in Vergils Äneis, Thesis, Heidelberg, 1972; C. SchINDlER, Untersu- 
the latter ones the ancient textbooks for learning Greek and Latin at school, ${ }^{27}$ one may safely assume that either exerted its influence on both Gregory and Augustine, who were excellently trained classical orators made bishops. ${ }^{28}$

However, what exactly is the rhetorical function of that multitude of similes in Gregory and Augustine? An answer to that is best approached by recalling those first two similes quoted to our minds. In both cases, a vivid image of ancient daily life unfolds before the mental eye: One virtually sees the vineyard protectively surrounded by a hedge of thornbushes, the vine shoot that does not stay inside the enclosure but penetrates the barrier and bears its fruit as though it was produced by the thornbush; and the weary wanderer, hungry and thirsty from a long and tiring journey, possibly under a hot Mediterranean sun, who needs to pick the desired refreshment very carefully lest he pricks and wounds himself.

The reader mentally sits at the banquet table and surveys the setup: among many other things knives and spoons with a pronged handle used for picking up bits and bites in the soup or from platters. And then a very unfortunate and totally uncalled for incident happens: one of the guests - maybe he is already intoxicated, or by way of a practical joke gone awry - cuts himself with his knife or uses his pronged spoon in order to poke at the eye of the person next to him.

Even just paraphrasing the similes one realizes that the mind imagines more than was actually said. One becomes personally and emotionally interested. Thus, similes are part of the three fundamental goals of any good rhetoric:

It has been said by a man of eloquence, and quite rightly, that the eloquent should speak in such a way as to instruct (docere), delight

chungen zu den Gleichnissen im römischen Lehrgedicht: Lucrez, Vergil, Manilius (Hypomnemata, 129), Göttingen, 2000, esp. S. 46-51, 150-215; W. J. O'NeAL, Ancient versus Modern Ways of Making Comparison. Comparatio in Vergil's Aeneid, Lewiston, N.Y., 2005.

(27) Cf. Marrou, Augustinus, pp. 3-73.

(28) Cf. A. Rousselle, "Aspects sociaux du recrutement ecclésiastique au IVe siècle," in Mélanges de l'École Française de Rome. Série 'Antiquité', 89 (1977), pp. 333-370; W. EcK, "Der Einfluß der konstantinischen Wende auf die Auswahl der Bischöfe im 4. und 5. Jahrhundert," in Chiron, 8 (1978), S. 561-585; A. Sterk, Renouncing the World Yet Leading the Church. The Monk-Bishop in Late Antiquity, Cambridge, MA, London, 2004, esp. pp. 95-118. 
(delectare), and move (movere) the listeners. He then added: 'instructing is a matter of necessity, delighting a matter of charm, and moving them a matter of conquest (Augustine, De doctrina christiana, IV 27, referring to Cicero, Orator, 69).

It is of utmost importance to see that delectare comes only second after docere, and before movere. The first aim of all rhetoric is to instruct. To do so in an enjoyable way is the appropriate tool, lest the audience stops listening out of boredom (taedium), which constitutes the primeval sin in rhetoric: "...bore our listeners, cloud their understanding, and stifle their desire to believe" (Aug., doctr. chr., IV 3).

In short, images, parables, and similes serve to achieve the fundamental aim of all rhetoric: to convince one's audience and move it to the desired action by presenting one's argument (docere) in such a clear and pleasantly acceptable way (delectare) that people follow one's instructions, in the case of Gregory and Augustine towards a perfect Christian life. This ties in with the three fundamental goals of the introduction to a speech or sermon, the prooemium: "...use an introduction to make the listeners favourable (benevolum), interested (intentum), and receptive (docilem)" (Aug., doctr. chr., IV 3). The fact that those images are particularly frequently to be found in Gregory of Nyssa's and Augustine of Hippo's sermons just proves their joint and peculiarly outstanding rhetorical mastery.

\section{Conclusion}

This short paper intends to encourage a more complete reading and analysis of the metaphors, parables, and similes in Late Antiquity texts in general and in Gregory of Nyssa and Augustine of Hippo in particular, because they use this rhetorical instrument with peculiar abundance and masterly skill.

Three levels need to be jointly considered: rhetorical, material, and theological-spiritual. However, without a thorough material analysis the other two stand on feet of clay. Only if the modern reader draws as close as possible to the imagination of the ancient audience by knowing the realia of their contemporary world as well as they did - as far as this is at all possible -, one will understand the rhetorical and theological-spiritual meaning correctly and fully.

Furthermore, this way of reading the texts with 'archaeological eyes' will also profit the historian and archaeologist of antiquity. On the one hand, it will add to the knowledge of the ancient material world be- 
yond the archaeologically excavated evidence, and on the other it will help to explain the findings of ancient realia, which oftentimes are open to a variety of interpretations.

This kind of mutual impregnation of texts and monuments will, I am sure, be extremely profitable and fertile, and draw a much richer and much more detailed image of ancient daily life than hitherto realized. It also promises to hold in store many a surprise which may change our view of the real ancient world considerably.

\section{SUMMARY}

While no direct dependency can be proved, one major common feature of Gregory of Nyssa's and Augustine of Hippo's sermons consists in their extraordinarily frequent homiletic use of parables, similes, and metaphors. Usually these images are interpreted regarding their theological and spiritual goals of instruction. However, only a detailed knowledge of the contemporary material world comprehensively unfolds their precise meaning. This is demonstrated by selected examples taken from the cultivation of vineyards, household utensils, and medicine (scalpels and cauterization irons). Also the rhetorical function of using images pursuing the basic aim of delectare is discussed, which - given the fact that both Gregory and Augustine were trained orators made bishops - follows both the Homeric and Virgilian poems and the Bible. 


\section{Plates}
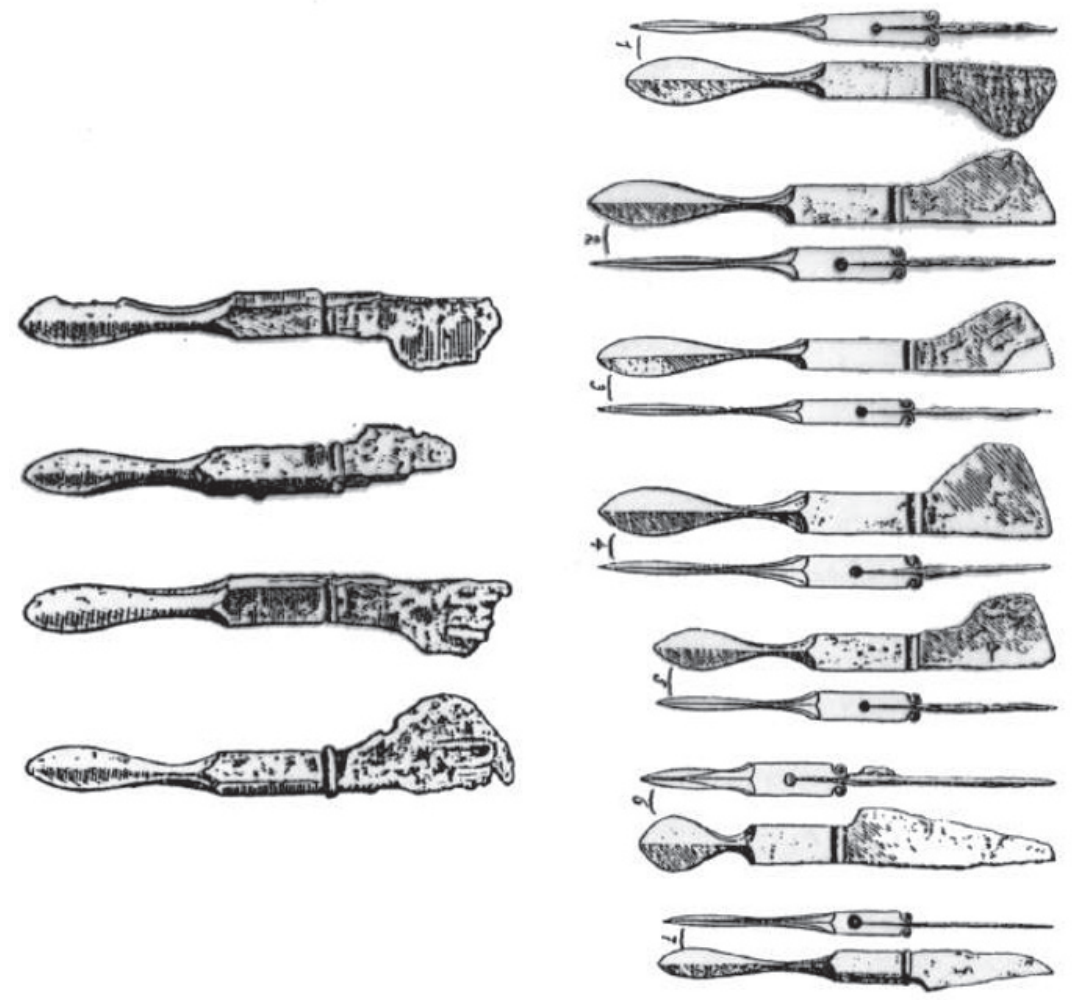

Pompei

Bingen

Plate 1: Roman scalpels from Pompei and Bingen (from: Matthäus, "Medizinische Instrumente," S. 315). 


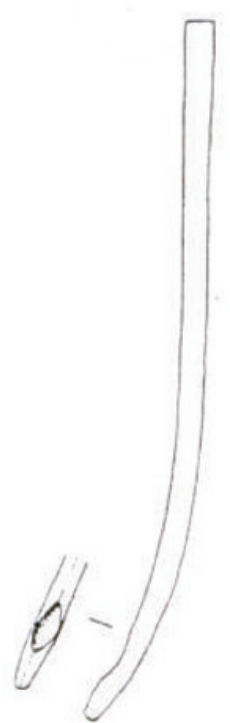

Olive

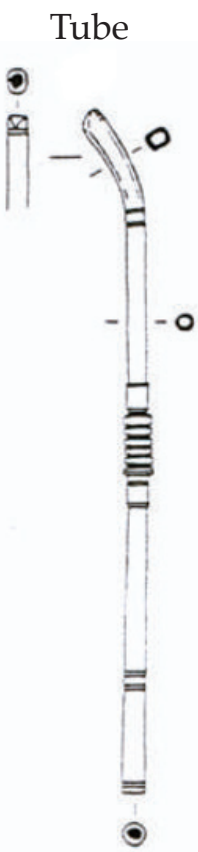

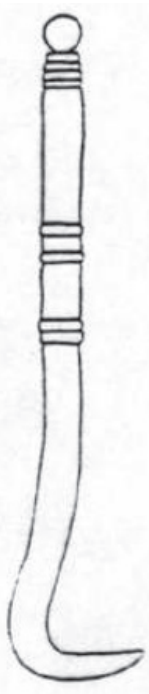

Sickle

Wedge

Spear

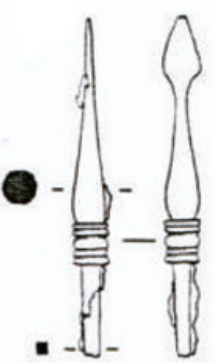

Plate 2: Cauterization irons

(from: Jackson, "Roman Medical Instruments," p. 127, fig. 3, and IDEM, "Roman Doctors and Their Instruments: Recent Research into Ancient Practice," Journal of Roman Archaeology, 3 [1990], p. 20, fig. 7). 


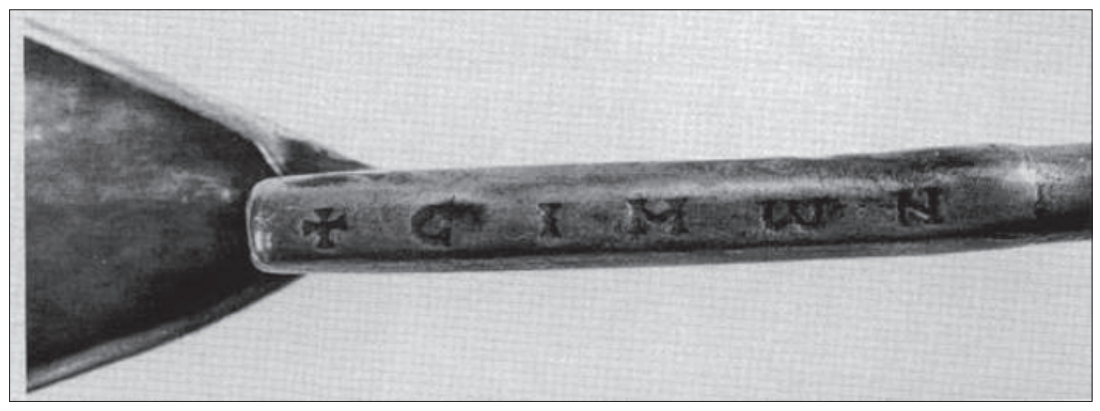

Plate 3: Silver spoon from Istanbul (from: Hauser, Spätantike Silberlöffel, Tafel 17).

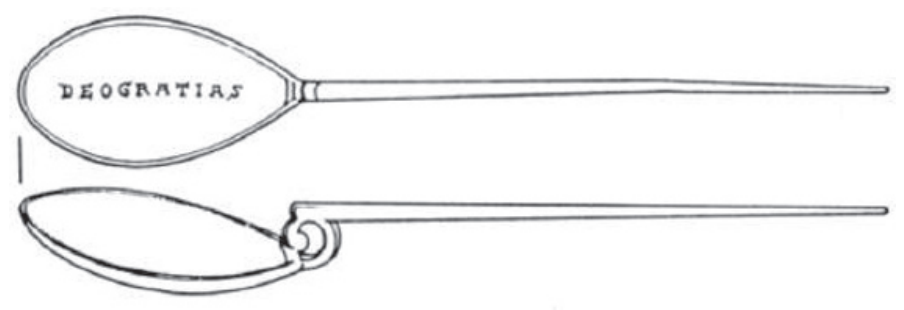

Plate 4: Silver spoon from Cologne-Müngersdorf (from: Hauser, Spätantike Silberlöffel, Tafel 3). 